\title{
Individual Features in the Contemporary Polish Reportage: A Syntactic and Stylistic Study on the Basis of Zabójca z miasta moreli: reportaje z Turcji by Witold Szabłowski
}

\author{
Katarzyna Ostrowska \\ Jan Kochanowski University, Poland \\ katarzyna.ostrowska@ujk.edu.pl
}

\begin{abstract}
The article deals with the individual features of language in the contemporary Polish reportage based on the text Zabójca z miasta moreli: reportaże z Turcji by Witold Szabłowski. The author presents both the statistical analysis and the stylistic peculiarities of this reportage which received a prestigious Beata Pawlak Award in 2011 and contains important components characteristic for the journalistic style. The author uses the traditional syntactic model of Zenon Klemensiewicz and takes into consideration Stanisław Jodtowski's research achievements. According to the postulates of Anna Wierzbicka, Maria Rachwałowa, Stanisław Mikołajczak, and Marek Ruszkowski, she selects a sample of 200 utterances which are examples of such narrative constructions that strongly indicate subjectivity. In her research, firstly, she conducts a detailed analysis of the syntactic and statistical features of Szabłowski's text in comparison with the style of the contemporary Polish reportage. Secondly, she draws attention to unique stylistic features indicating the reporting syntax. As a result, the author notices the following individual features of language in Zabójca $\mathrm{z}$ miasta moreli: reportaże $\mathrm{z}$ Turcji by Witold Szabłowski: 1) simple utterances and direct and indirect objects in the developed sentences, 2) developed clauses and adverbials, 3) objective hypotaxis, and 4) adverbial hypotaxis.
\end{abstract}

Keywords: reporting syntax, stylistic peculiarities, journalistic style, factuality

Streszczenie

Językowe indywidualizmy we współczesnym polskim reportażu. Studium składniowostylistyczne (na podstawie tekstu Zabójca z miasta moreli. Reportaże z Turcji Witolda

Szabłowskiego)

Artykuł traktuje o językowych indywidualizmach we współczesnym polskim reportażu na podstawie tekstu Zabójca z miasta moreli. Reportaże z Turcji Witolda Szabłowskiego. Autorka prezentuje zarówno statystyczny ksztalt, jak i stylistyczne osobliwości omawianego reportażu, który został wyróżniony Nagroda im. Beaty Pawlak w 2011 roku oraz zawiera ważne wyróżniki charakterystyczne dla stylu publicystycznego. Ramy znaczeniowe terminu reportaż określa, 
posiłkując się definicjami Janusza Stawińskiego, Czesława Niedzielskiego oraz Juliana Maślanki. W swojej pracy używa tradycyjnego modelu składniowego Zenona Klemensiewicza, uwzględniając ważne osiagnięcia naukowe Stanisława Jodłowskiego. Zgodnie z postulatami Anny Wierzbickiej, Marii Rachwałowej, Stanisława Mikołajczaka oraz Marka Ruszkowskiego spośród konstrukcji narracyjnych, które silnie wpływają na podmiotowość stylu, dobiera próbe równa 200 wypowiedzeń. W badaniach w pierwszej kolejności dokonuje szczegółowej analizy syntaktycznego $i$ stylistycznego ksztattu tekstu Szabłowskiego $w$ porównaniu do stylu współczesnego polskiego reportażu. Następnie zwraca szczególna uwagę na stylistyczne indywidualizmy wskazujace na wykorzystanie składni sprawozdawczo-raportujacej. $\quad W$ rezultacie autorka zauważa, że w reportażu Zabójca z miasta moreli. Reportaże z Turcji Witolda Szabłowskiego 1) przewaga konstrukcji pojedynczych oraz dopetnień w zdaniach rozwiniętych świadcza o dynamizacji akcji, 2) często używane w konstrukcjach rozwiniętych okoliczniki potęuja dokumentarność, 3) zdania hipotaktyczne dopetnieniowe wskazuja na raportowanie $i$ przytaczanie, 4) zdania złożone podrzędnie okolicznikowo petnia stylistyczna funkcje eksplikacyjna.

Słowa kluczowe: składnia sprawozdawcza, stylistyczne indywidualizmy, styl publicystyczny, dokumentalność

\section{Introduction}

The research of linguistic features in the contemporary Polish reportage is an interesting but also undeveloped theme. The reportage style is generally located between the journalistic, scientific and literary style and has its linguistic determinants ${ }^{1}$. Characteristic features of the journalistic style are the reporting syntax, undeveloped sentences as well as the number of adverbials, objects, equivalent sentences, and notifications. The scientific style stands out because of the interpretative syntax and hypotactic-paratactic constructions, whereas the literary style is marked out by the descriptive syntax, narrative structures, developed sentences, and a high number of attributives. According to Kazimierz Wolny-Zmorzyński, Andrzej Kaliszewski and Wojciech Furman (2006: 68-69), the basic features of the reportage style are the presence of the narrator, the usage of dialogue, the individualization of the characters' language, impressive descriptions, the authenticity of events, the accuracy of names, surnames, dates, numbers, and facts as well as the use of specific terminology and the maintaining of objectivity. It is also worth highlighting other monographs connected with the reportage style written by Kazimierz Wolny-Zmorzyński (2004), Walery Pisarek (2007), and Maria Wojtak (2010). This article aims to present both the statistical analysis and the stylistic peculiarities of the text Zabójca z miasta moreli: reportaże z Turcji written by Witold Szabłowki. It is important to emphasize that all percentage relations come from my doctoral thesis connected with the syntactic investigation of

\footnotetext{
${ }^{1}$ I will deal with the issue of syntactic terminology in detail in the next part of this article.
} 
the contemporary Polish reportage. Moreover, due to the lack of an English version of the investigated reportage, I translated all the citations myself from Polish.

In this article, I regard the reportage as a genre of statements that reports the authentic occurrences in which the author participated or found direct witnesses (Sławiński 1988: 431432; Niedzielski 1985: 280-282; Maślanka 1976: 213-215) and that has syntactic features of the literary, journalistic and scientific styles, manifested in descriptive, reporting, and interpretative syntax. I do not use the term literary reportage as it indicates similarity only to the literary style. For this research, I chose Szabłowski's novel for some important reasons. Firstly, this reportage was prized a prestigious Beata Pawlak Award in 2011. Secondly, it possesses crucial individual features of language. Thirdly, it contains important components of reporting syntax.

In my research, I used the quantitative analysis method, which consists of four basic stages: observation and collection of quantitative facts, syntactic analysis, measuring of phenomena, and interpretation used to discover the stylistic functions. In the first part I used the representative method which allows to infer the total population based on the sample. I took into account the following features when choosing the sample: it had to be uniform, large enough, randomly collected, and dispersed ${ }^{2}$ (Kniagininowa 1962: 95; Ruszkowski 1997).

Based on the accomplishments of authorities such as Anna Wierzbicka (1966: 172), Maria Rachwałowa (1986: 51), Stanisław Mikołajczak (1990: 20), and Marek Ruszkowski (1997: 24), I investigated 200 utterances from the narrative parts of the reportage which I focused on. At the same time, I observed all the syntactic structures from Zabójca z miasta moreli: reportaże z Turcji. Taking into account the significant subjective aspect of the reportage, I accept the constructions from the narration as uniform and more dependent on the author part (than on the dialogical forms) of the text (Sławiński 1988: 303; Głowiński 1973: 59-76). I used a dependent random draw pattern ${ }^{3}$, limited in layers. As a result, I found the report pages to be the smallest random element and used a random number generator. I drew 20 numbers that corresponded to specific pages of the report, and then I performed a syntactic analysis of 10 narrative statements on each page. As a consequence, I examined 200 syntactic structures in this reportage. It is important to highlight that I took into account all of the sentences from the dialogue and narrative parts to discover the relationship between these two types of expression.

\footnotetext{
${ }^{2}$ The sample is dispersed from the smaller sections of text, equal in length into which it was previously divided.

${ }^{3}$ Generator liczb losowych: [Source: https://www.naukowiec.org/kalkulatory/liczby-losowe.html. Date: 18.07.2020].
} 
In the second stage, from among the several syntactic models represented by Zuzanna Topolińska (1984), Zygmunt Saloni (1985), Marek Świdziński (1985), and Ireneusz Bobrowski (1995), I chose the traditional syntactic methodology of Zenon Klemensiewicz $(1969,1982)$ and reviewed Stanisław Jodłowski’s (1976) research achievements. This kind of syntactic method brings the best results in stylistic studies, determines crucial components of teenage education, is deeply located in social consciousness (Jaroszak 2003: 13-14), and provides a comparative background (Zagórski 2006: 247-267).

The third stage of the research was the estimation of phenomena in which I used the arithmetic mean as the most important statistical parameter.

The last part of the analysis was the interpretation of the phenomena used to present the functions of individual syntactic constructions.

\section{The statistical analysis}

It is worth presenting the general syntactic and statistical analysis characteristics of Szabłowski's text in comparison with those of the contemporary Polish reportage. Based on my doctoral thesis, I assume that this novel is in the group of reportages that have syntactic elements suitable for the journalistic style and reporting syntax.

Firstly, the relation between the narrative and dialogue utterances in the case of the contemporary Polish reportage amounts to $90 \%$ and 10\%, respectively. In Szabłowski's Zabójca $z$ miasta moreli: reportaze $z$ Turcji this proportion is on average $88 \%$ to $12 \%$ which indicates the strong subjective aspect as well. The reporter presents reflections, observations, actions, and conducted interviews, and, in this way, affects the factuality of this genre. The high rate of dialogues testifies to the subjectivity of the statements. The lower the narrative ratio, the greater the expressiveness. Sometimes the author identifies with the characters, relates from their point of view, and provides relevant information (Mikołajczak 1983: 16-17). As a result, the reporting subject gains the position of an expert, who collects the documents related to a given theme, visits a place, and conducts conversations with the conflict parties. The key point is also the limitation of the author's assessment which should be done individually by the reportage's reader.

Secondly, in the contemporary Polish reportage the relation between simple and complex sentences amounts to $43 \%$ and $57 \%$, respectively. It means that the predominance of complex sentences testifies to the reportage style. In Szabłowski's text, this proportion is on average $64 \%$ to $36 \%$. It is worth to note that from all of the researched reportages studied in my doctoral 
thesis, this novel has the highest number of simple utterances. This affects presenting particular facts, ordering them chronologically, and, as a result, highlighting the reporting syntax and simplicity in presenting the plots. In this way, it reveals the importance of simple utterances that perform a significant role in creating the stylistic analysis of this reportage.

Thirdly, the proportion between the verbal and verbless utterances in the contemporary Polish reportage is on average $35 \%$ to $8 \%$. According to Jodłowski (1976: 35 ), the verbal ones are the constructions with a personal verb form, an impersonal verb form (in which the role of the predicate is played by past tenses), or a modal verb (need, can). However, the verbless structures do not contain a predicate, but allow for its introduction (in an equivalent utterance) or do not allow for such a possibility (in a notification). The novel Zabójca z miasta moreli: reportaze $z$ Turcji distinguishes a rate which amounts to $54.5 \%$ in the case of verbal structures and $9.5 \%$ in the case of verbless ones. Therefore, the highest percentage of verbal constructions (from all of the researched reportages) makes the developed and undeveloped sentences extremely crucial for this article. By the term developed sentence, I mean a construction with a predicate and attributives, objects, or adverbials or a construction with a subject and a predicate with attributives, objects, or adverbials (Klemensiewicz 1982: 447-448), while I consider a structure that has only the subject and the predicate or the predicate itself to be an undeveloped sentence. In this reportage, the developed sentences cover $48 \%$ of the narrative parts. These constructions are rather short and are characterized by a medium length of words and a vertical profile. Just as Marek Ruszkowski (2004), I consider the medium length of structures as the number of elements in the sentence. Along with the length of the notice, its semantic value increases which should not be combined with the precision of the communicative structure. The term vertical profile means the maximum number of degrees at which the structural arrangement of an utterance is built (Mikołajczak 1983: 38). In my opinion, the subject and the predicate define each other and are at a zero degree. Therefore, it should be understood that the developed sentences have a minimum first degree of layering profile, and undeveloped clauses remain at zero (Ruszkowski 2004). The medium length of words is 5,4 elements and the medium vertical profile is 1,6 . As a result, simple sentences are carriers of specific, simple, and autonomous information. Concerning the undeveloped sentences, they cover almost $6.5 \%$ of all sentences. From a stylistic point of view, undeveloped constructions are rarely used to construct larger parts of a text, because of their low communicative function and their necessity to be well located in the context.

Moreover, in the typical contemporary Polish reportage, the proportion between the descriptive vocabulary amounts to 54\% (attributives), 25\% (adverbials) and 21\% (objects). 
According to Zenon Klemensiewicz (1969: 56) the most general function of an attributive is to determine the characteristics of the subject. As a result, the subject can be distinguished from other similar objects. An adverbial, on the other hand, is defined as a circumstance which provides some additional accompanying detail (Klemensiewicz 1969: 48), while the term object is connected with the action and condition of the predicate (Klemensiewicz 1969: 40). It is worth presenting the occurrences of the descriptive words (among the developed sentences) appearing in Szabłowski's text: attributives - almost 44\%, adverbials - about 30\%, and objects approximately $27 \%$. Unquestionably the rate of attributives is the highest, but, in this case, the percentage of adverbials and objects deserves further considerations. Adverbials situate actions in time, space, and determine all possible circumstances (Żak-Święcicka 1993: 92). In Małgorzata Rybka's (2002: 94) opinion, the objects are the most dynamic part of the syntax, as they make the sentence more energetic and, at the same time, refer to the patterns of spoken Polish. It means that objects occur more often in spoken than in written Polish.

What is more, as I presented above, in Zabójca z miasta moreli: reportaże z Turcji the sentences which appear the least frequently are the complex sentences. In Stanisław Mikołajczak's opinion (1990: 133), complex sentences constitute the most meaningful syntactic elements of a literary reportage. These structures cover only $36 \%$ of all constructions. From among the complex sentences, I mark out the hypotaxis, parataxis, hypotactic-paratactic utterances, combined utterances, and internally established utterances. Hypotaxis is the relationship of two syntactic clauses, one of which is dependent on the other (Gołąb, Heinz, Polański 1970a: 233). Parataxis is such a relationship of two syntactic clauses, whose meanings are logically equivalent to each other, while the syntactic form of neither of them depends on the other clause (Gołąb, Heinz, Polański 1970b: 412). Hypotactic-paratactic clauses consist of both paratactic and hypotactic sentences. Combined utterances collate two or several utterances into one, based on some approximation of the content contained in these utterances (Klemensiewicz 1982: 474). Internally established utterances consist of several sentences between which certain syntactic relations occur (Ruszkowski 1997: 200). The level of hypotaxis is $16.5 \%$, of parataxis $9 \%$, of hypotactic-paratactic sentences $7.5 \%$, of combined utterances $2 \%$, and of internally established utterances only $1 \%$. In the contemporary Polish reportage these rates amount on average to $21 \%, 13 \%, 13 \%, 7 \%$, and $3 \%$, respectively. Crucial for this research are the hypotaxis constructions from which the most common are objective (about 51\%) and adverbial (almost 39\%) ones. Short hypotaxis sentences consist of 7,5 elements with a vertical profile of approximately 2,2 . 


\section{Stylistic peculiarities}

As I presented above, Witold Szabłowski's reportage is unique because of the statistical analysis of some syntactic constructions which indicate the reporting syntax peculiar to the journalistic style. Zabójca z miasta moreli: reportaże z Turcji is unusual due to these reasons: 1) clear dominance of simple utterances, among which there are verbal ones (developed and undeveloped sentences), 2) predominance of adverbials and objects in developed structures, 3 ) explicit prevalence of objective and adverbial hypotaxis. I illustrate all of these characteristics below.

\subsection{Developed and undeveloped sentences}

The first distinguishing mark in Witold Szabłowski's reportage is the prevalence of verbal sentences (developed and undeveloped constructions) which cover $54.5 \%$ of all the constructions. According to Zenon Klemensiewicz (1982: 447-448), simple developed sentences play an important stylistic role, especially, when their rate is above or below the averaged $30 \%$ presence. In the researched text this rate is extremely high and amounts to $48 \%$ which suggests unusual stylistic functions.

The researched reportage is characterized by the usage of the descriptive stylistic function to 1) construct larger parts of the text separated by the help of paragraphs and to 2) describe real situations connected with the protagonists. In the below utterances, the reporter introduces the exact situations (using dates: June 3, 1963, in 2002, in September 2008) and portrays the protagonists' biographies (by using such verbs: to die, to pass, to not set, to apply, to divide, to be at odds with, to release, to be), e.g.:

Nazım Hikmet Borzęcki died on June 3, 1963. Exactly three years and two months after his marriage to Vera. Twelve years have passed since his escape. He did not set foot on Turkish soil until his death.

(Szabłowski 2010: 39)

In 2002, Memed Hikmet Borzęcki applied for the restoration of Turkish citizenship. Is approved. Today he divides his life between Istanbul and Paris. He is at odds with a large part of the family. They don't understand why he doesn't want to talk about his famous father.

(Szabłowski 2010: 40)

In September 2008 Ahmet Baba sent out some dinghies from Behramkale. From here it is only five kilometres in a straight line to the Greek coast.

(Szabłowski 2010: 151) 
What is more, the descriptive function is also abused to present important Turkish places, like Istanbul, and, as a result, to highlight the contrast between wealth and poverty. The below paragraph serves to illustrate two parts of Istanbul: the first one - rich (opened for the tourists), and the second one - poor (reserved for the hard-working natives), e.g.:

There are two Istanbuls.

The first one belongs to the tourists, five-star hotels and party-goers. This is where Orhan Pamuk seeks the sources of his nostalgia, while Japanese visitors draped in cameras photograph every millimetre of it. Each year over ten million tourists come here, with over thirty million visiting the country as a whole. Almost ten per cent of the Turkish budget comes out of their pockets. (...)

But these days the real bridge is the other Istanbul. To see it, you have to step off the tourist trail and into the side streets, and then sharpen your vision.

But the real bridge is the second Istanbul now. To see it, you have to get off the tourist promenade into the side streets and sharpen your eyesight.

Then you can see the Africans using the last of their energy to pull carts laden with scrap metal, the Chinese slicing cucumbers for kebabs in a basement, or the Indians selling fake perfume, with bags under their eyes that have stuck to their faces for good (...).

(Szabłowski 2010: 141)

Among the verbal utterances, we can also mark out the undeveloped simple sentences, which in the contemporary Polish reportage cover about $2 \%$ of all constructions. The reportage Zabójca $z$ miasta moreli: reportaże $z$ Turcji is unique due to the unusually high percentage of these constructions - 6.5\%, which indicates an individuality distinguishing mark. Normally, undeveloped constructions are used to 1) dynamize action, 2) introduce the plot, and 3) briefly conclude the assumptions. It is worth presenting all of these functions which are present in Szabłowski’s text.

Firstly, the dynamization function intensifies both the imagery and pace. Therefore, it forces the reader to focus on the run of events (without accompanying circumstances) and constitute the laconic description of the situation. In this way, the reporter highlights important themes and short conclusions connected with the truth (truth does not free) and happenings (nothing happens), e.g.:

Rumor is more important than truth. Truth does not free. Only what they say is important.

(Szabłowski 2010: 99) 
It is hard for me to walk around Diyarbakıra with this knowledge. I walk on the side streets. Children have holes in their shoes here, and their mothers spend their days sitting on the porches and gossiping. Nothing happens. And suddenly a green dot appears on the horizon. It grows but does not turn into any familiar figure. The head is looking for the right word. And finds it: yabancl, a foreigner.

(Szabłowski 2010: 99)

Secondly, the undeveloped constructions play the role of announcing a certain topic that will be expanded in the other structures of this part. As a result, the narrator introduces an issue about a woman succeeding in finding a shelter (managed to) and a situation about the way how two protagonists met (Rabya is a journalist), e.g.:

Managed to. At the foundation's headquarters, volunteers heard her history. They helped her find a women's shelter and promised mediation.

(Szabłowski 2010: 105)

Rabya is a journalist. A few years ago she went to interview A $\breve{g c a}$. That's how they met.

(Szabłowski 2010: 180)

Thirdly, the concluding stylistic function of undeveloped sentences is frequently used as a summary of previously expressed content or as the closing of a passage. The reporter uses the undeveloped sentences to both sum up (in a philosophical way) the plot connected with death and present the effectiveness of the character's actions, e.g.:

They sail out towards the Greek island of Lesbos in the evening. Halfway up they hit a storm. The wind tears the sails. It tosses the boat. Waves flooding the deck. Everyone falls into the water. Death is there.

(Szabłowski 2010: 35)

Ahmet didn't want to talk. His family told him that his wife had run away with another man.

When he found out that she was in the women's shelter all the time, he only said: "Let her come back".

And Hatice came back.

(Szabłowski 2010: 109-110)

To sum up, the high rate of simple utterances - developed and undeveloped sentences in the researched text strongly indicates the reporting syntax, and, as a result, the journalistic style. The developed structures highlight the descriptive function connected with crucial situations, 
characteristics, and places. On the other hand, the undeveloped clauses deeply dynamize, announce and summarize the occurrences.

\subsection{Adverbials and objects in developed sentences}

The second stylistic peculiarity of the reportage Zabójca z miasta moreli: reportaże z Turcji by Witold Szabłowski is an exceptional rate of descriptive words in developed sentences. They amount to almost $44 \%$ on the attributive level, to about $30 \%$ on the adverbial level, and to approximately $27 \%$ on the object level. To compare, in the contemporary Polish reportage the attributives cover about $54 \%$, adverbials $-25 \%$, and the objects $-21 \%$. It means that the static relations are limited in favour of high dynamization using adverbials and objects.

First of all, adverbials constitute the most semantically diverse class and specify time, place, goals, causes, or effects. They perform a semantic modifying function because they connect with the predicate on an optional basis (Pisarkowa 1984: 66). Therefore, the adverbials highlight the semantic modifying function in the contemporary Polish reportage and additionally serve to 1) illustrate behaviour or manner, 2) underline the time, and 3) locate the place.

The first stylistic function emphasizes the mode of something (from the inside, up to his ears, in this way), which is supplementary information for the reader. As a result, this information could be removed from the text without changing the meaning of the utterances, e.g.:

This ambition devoured him from the inside like a worm.

(Szabłowski 2010: 44)

Sulejman was in love with her up to his ears.

(Szabłowski 2010: 44)

In this way, he left a suppurative ulcer in the center of his new capital.

(Szabłowski 2010: 45)

The second important temporal stylistic function serves to highlight the time of the situation. In this way, we can approve that for simple developed sentences locating in time is a certainly crucial stylistic function that informs about continuity (through his long life, for fourteen years) as well as about past (two weeks earlier), present (today), and future occurrences (then, a few months later), e.g.:

Supposedly, he was ambitious as hell already then.

(Szabłowski 2010: 44) 
Today they sell carpets in it.

(Szabłowski 2010: 44)

Through his long life, he built mosques, madrassas, Koranic schools, hospitals, caravanserais, aqueducts, palaces, and baths.

(Szabłowski 2010: 44)

It was the sultan who died a few months later.

(Szabłowski 2010: 47)

The architect lived for fourteen years.

(Szabłowski 2010: 47)

Two weeks earlier, in the town of Silvan a husband killed his wife.

(Szabłowski 2010: 94)

The third stylistic function presents the places connected with the theme of the reportage. This unique space is combined with cities (Bosporus, Hagia Sophia), historic monuments (Blue Mosque), and ordinary places (hospital, mosque), e.g.:

Hamam stands in Istanbul between Hagia Sophia and the Blue Mosque.

(Szabłowski 2010: 44)

The poor do it in the hospital, under insurance.

The film erupted pornography over the Bosporus.

(Szabłowski 2010: 61)

Aytekin, a volunteer, is waiting for men outside the mosque.

(Szabłowski 2010: 62)

Second of all, in developed sentences, we observe the objects that combine with the predicate on an obligatory basis, and, as a result, complete the utterance's content (Rybka 2002: 94). In consequence, the objects play a crucial stylistic dynamization function. They carry important information in the sentence without which the utterance would be incomplete, e.g.:

He had crumpled pants, a sweater which was out of fashion, and horn glasses.

(Szabłowski 2010: 43)

Several independent committees are fighting for permission to build the monument.

(Szabłowski 2010: 42)

At the end of the fifties, she marries a colleague from the editorial office.

(Szabłowski 2010: 54)

Promotes virginity, loyalty, and integrity.

(Szabłowski 2010: 54) 
Concluding these deliberations, the adverbials and objects in the developed structures are important as they affect the factuality, and, in this way, influence the reporting syntax. The adverbials play the supplementary, temporary, and locating role, while, the objects emphasize dynamization.

\subsection{Objective and adverbial hypotaxis}

The third language individual feature of Witold Szabłowski's text Zabójca z miasta moreli: reportaże $z$ Turcji is a clear predominance of objective constructions $-51 \%$. The statistical appearance of the other structures is manifested by the adverbial (almost 39\%) and attributive (approximately 10\%) types which affect the reportage style.

To compare, in the typical contemporary Polish reportage the following types exist the most frequently among the hypotaxis sentences: the adverbial type (on a rate of about $35 \%$ ), then the objective (almost $34 \%$ ), and the attributive (21\%). Moreover, we distinguish also the developing $(8 \%)$ and subjective (2\%) kind. Generally, all hypotaxis constructions serve three stylistic functions: explication, reporting, and quoting.

I would like to approach the theme of objective hypotaxis due to its extremely high level in the investigated reportage. According to Zenon Klemensiewicz (1969: 98), it illustrates the content, in which the superior clause contains the elements that have to be completed. As a result, the objective hypotaxis plays stylistic reporting and quoting functions. By using this type of construction, the narrator reports all of the occurrences (of which he was a witness) and quotes the characters' utterances. He appeals to the following categories: knowledge (to know that, to learn that), understanding (to understand that), conviction (to believe that), communication (to mention that, to ask if, to say that) and writing (to write that), e.g.:

Poles believe that the construction of the Polish version of socialism is finally beginning.

(Szabłowski 2010: 28)

Gota mentions that Nazım was friends with Broniewski.

(Szabłowski 2010: 30)

Münevver learns for the first time that her husband is a woman with another woman.

(Szabłowski 2010: 35)

Nazım from Warsaw writes to her in a letter that she went to heaven, even "if the Pope disagreed with this".

(Szabłowski 2010: 36)

The rich man hosted him generously and Kurd knows that he will not be able to repay him all his life. 
(Szabłowski 2010: 36)

Mustafa asks if we cannot afford a train or a plane.

(Szabłowski 2010: 68)

He also understood that a brawl is not the best idea.

(Szabłowski 2010: 69)

They say that they have had enough of Islamist rule.

(Szabłowski 2010: 73)

Moreover, second in terms of the frequency in Witold Szabłowski's reportage is the adverbial type of hypotaxis. This kind of construction specifies simultaneous, earlier or later occurrences, and indicates the desired succession (Klemensiewicz 1969: 92). In this way, it performs the stylistic explication function. The narrator explains the time of the happenings (Viera breaks when, the world froze when, before Tel Aviv broke down) and the purpose of some actions (they trim so that, to understand I met). In this way, the reader inquiries crucial knowledge about the causes and effects, e.g.:

Viera breaks when Hikmet is in Warsaw.

(Szabłowski 2010: 33)

That is why the world froze when the election in Turkey was won by gentlemen with a fivemillimeter mustache.

(Szabłowski 2010: 72)

They trim them so that they are no more than five millimeters long.

(Szabłowski 2010: 72)

To better understand Erdoğan's war with the Kemalists, I met with Fehmi Koru, journalist of "Yeni Şafak", a daily known for his sympathy for Islam.

(Szabłowski 2010: 88)

However, before this happened, Ankara's traditionally good relations with Tel Aviv broke down.

(Szabłowski 2010: 89)

Summing up, the objective hypotaxis indicates the reporting and quoting function and points at semantic fields connected with knowledge, understanding, convictions, communication, and writing. Besides, the adverbial hypotaxis presents the time and the purpose of all happenings. In this way, these two types of hypotaxis structures present a strong connection with journalistic reportages. 


\section{Conclusion}

Concluding, Witold Szabłowki's reportage Zabójca z miasta moreli: reportaże z Turcji unquestionably has unique features of language in comparison with the pattern of the contemporary Polish reportage style. This text contains unique characteristics that indicate the reporting syntax, and strengthen the factuality and dynamization role, crucial for the journalistic style.

At the end of this research, based on the comparative analysis, I would like to sum up below both the statistic and stylistic peculiarities.

Firstly, the proportion between the narrative and dialogue utterances in this reportage is typical and amounts to $88 \%$ and $12 \%$, respectively, which indicates both the factuality and subjectivity of this genre.

Secondly, the relation between the simple and complex sentences is on average $64 \%$ to $36 \%$. In this way, it affects the simplicity, the chronological way of presenting facts, and especially the reporting syntax.

Thirdly, in Szabłowski's text, the rate between the verbal and verbless utterances amounts to $54.5 \%$ and $9.5 \%$. An extremely high number of developed sentences that cover $48 \%$ of the narrative parts influence the autonomous information. The descriptive stylistic function of developed constructions serves to present the exact situations and important places, and to portray the protagonists' biographies. Moreover, in the analyzed novel, the undeveloped sentences are on the level of $6.5 \%$ and are used to 1) dynamize action (by highlighting important themes and short conclusions), 2) announce the plot (which is then expanded in the other structures), and 3) sum up the assumptions.

What is more, the occurrence of the descriptive words (among the developed clauses) is on the level of $44 \%$ for attributives, $30 \%$ for adverbials, and $27 \%$ for objects. In this case, the percentage of adverbials and objects is crucial for further considerations. First of all, the adverbials perform three stylistic functions: 1) supplementing (presenting the mode of something), 2) locating in time (combining continuity with past, present, and future occurrences), and 3) locating in space (illustrating cities, ordinary places, and historic monuments). Furthermore, the objects complete the content of the utterances and are the most dynamic part of the syntax (ensuring important information).

Moreover, in this text, the percentage of hypotaxis is $16.5 \%$. From among all hypotaxis constructions, the objective type covers $51 \%$, the adverbial almost $39 \%$, and the attributive about $10 \%$. The objective one performs the reporting and quoting functions and refers to the following 
semantic categories: 1) knowledge, 2) understanding, 3) convictions, 4) communication, and 5) writing. However, the adverbial type indicates the explication function by presenting 1) the time of happenings (simultaneous, earlier, or later events), and 2) the purpose of some actions.

Finally, the reportage Zabójca z miasta moreli: reportaże z Turcji by Witold Szabłowski has distinguishing features that strongly affect the journalistic style by 1) dynamizing the action by the help of simple utterances (among which there are undeveloped structures) and objects (in the developed sentences), 2) strengthening the factuality through the use of developed clauses and adverbials, 3) reporting and quoting by means of objective hypotaxis, and 4) explaining adverbial hypotaxis.

\section{References}

Bobrowski, Ireneusz (1995) Gramatyka opisowa języka polskiego (Zarys modelu generatywnotransformacyjnego). Struktury wyjściowe. Kielce: Wyższa Szkoła Pedagogiczna im. Jana Kochanowskiego.

Generator liczb losowych: [Retrieved from: https://www.naukowiec.org/kalkulatory/liczbylosowe.html. Date: 18.07.2020].

Głowiński, Michał (1973) „O powieści w pierwszej osobie.” [In:] Michał Głowiński (ed.) Gry powieściowe: szkice $z$ teorii $i$ historii form narracyjnych. Warszawa: Państwowe Wydawnictwo Naukowe; 59-76.

Gołąb, Zbigniew, Adam Heinz, Kazimierz Polański (1970a) “Hipotaksa (podrzędność).” [In:] Adam Heinz, Tadeusz Milewski (eds.) Stownik terminologii językoznawczej. Warszawa: Wydawnictwo Naukowe PWN; 233.

Gołąb, Zbigniew, Adam Heinz, Kazimierz Polański (1970b) “Parataksa (współrzędność).” [In:] Adam Heinz, Tadeusz Milewski (eds.) Słownik terminologii językoznawczej. Warszawa: Wydawnictwo Naukowe PWN; 412.

Jaroszak, Zenobia (2003) Składnia i styl wypracowań licealistów. Słupsk: Wydawnictwo Pomorskiej Akademii Pedagogicznej w Słupsku.

Jodłowski, Stanisław (1976) Podstawy polskiej składni. Warszawa: Państwowe Wydawnictwo Naukowe.

Klemensiewicz, Zenon (1969) Zarys składni polskiej. Warszawa: Wydawnictwo Naukowe PWN. 
Klemensiewicz, Zenon (1982) "Problematyka składniowej interpretacji stylu." [In:] Anna Kałkowska (ed.) Składnia, stylistyka, pedagogika językowa. Wybór prac. Warszawa: Wydawnictwo Naukowe PWN; 433-496.

Kniagininowa, Maria (1962) "Próba zastosowania metod statystycznych w badaniach stylistyczno-składniowych.” Język Polski 42 (1-2); 92-116.

Maślanka, Julian (1976) “Reportaż.” [In:] Julian Maślanka (ed.) Encyklopedia wiedzy o prasie. Wrocław: Zakład Narodowy im. Ossolińskich; 213-215.

Mikołajczak, Stanisław (1983) Składnia wybranych utworów Bolesława Prusa i Stefana Żeromskiego. Poznań: Wydawnictwo Naukowe UAM.

Mikołajczak, Stanisław (1990) Składnia tekstów naukowych. Dyscypliny humanistyczne. Poznań: Wydawnictwo Naukowe UAM.

Niedzielski, Czesław (1985) "Reportaż.” [In:] Artur Hutnikiewicz, Andrzej Lam (eds.) Literatura polska XX wieku. Przewodnik encyklopedyczny. Vol. 2. Warszawa: Wydawnictwo Naukowe PWN; 280-282.

Pisarek, Walery (2007) O mediach i języku. Kraków: Universitas.

Pisarkowa, Krystyna (1984) Historia składni języka polskiego. Wrocław: Zakład Narodowy im. Ossolińskich.

Rachwałowa, Maria (1986) Słownictwo tekstów naukowych. Wrocław: Zakład Narodowy im. Ossolińskich.

Ruszkowski, Marek (1997) Główne tendencje syntaktyczne w polskiej prozie artystycznej dwudziestolecia międzywojennego. Kielce: Wyższa Szkoła Pedagogiczna im. Jana Kochanowskiego.

Ruszkowski, Marek (2004) Statystyka w badaniach stylistyczno-składniowych. Kielce: Wydawnictwo Akademii Świętokrzyskiej.

Rybka, Małgorzata (2002) Zamieszkać w zdaniu. O składni tekstów poetyckich Czesława Miłosza. Poznań: Wydawnictwo WiS.

Saloni, Zygmunt, Marek Świdziński (1985) Składnia współczesnego języka polskiego. Warszawa: Wydawnictwo Naukowe PWN.

Sławiński, Janusz (1988) “Narracja.” [In:] Janusz Sławiński (ed.) Słownik terminów literackich. Vol. II. Wrocław: Zakład Narodowy im. Ossolińskich; 303.

Sławiński, Janusz (1988) “Reportaż.” [In:] Janusz Sławiński (ed.) Słownik terminów literackich. Vol. II. Wrocław: Zakład Narodowy im. Ossolińskich; 431-432.

Szabłowski, Witold (2010) Zabójca z miasta moreli, Wołowiec: Wydawnictwo Czarne. 
Wierzbicka, Anna (1966) System sktadniowo-stylistyczny prozy polskiego renesansu. Warszawa: Państwowy Instytut Wydawniczy.

Tokarski, Ryszard (1984) Struktura pola znaczeniowego (studium językoznawcze). Warszawa: Państwowe Wydawnictwo Naukowe.

Topolińska, Zuzanna (1977) "Mechanizmy nominalizacji w języku polskim.” [In:] Zuzanna Topolińska (ed.) Studia gramatyczne I. Wrocław: Zakład Narodowy im. Ossolińskich; 175212.

Wojtak, Maria (2010) Analiza gatunków prasowych: podręcznik dla studentów dziennikarstwa i kierunków pokrewnych. Lublin: Wydawnictwo Uniwersytetu Marii Curie-Skłodowskiej.

Wolny-Zmorzyński, Kazimierz, Andrzej Kaliszewski, Wojciech Furman (2006) Gatunki dziennikarskie. Teoria. Praktyka. Język. Warszawa: Wydawnictwa Akademickie i Profesjonalne.

Wolny-Zmorzyński, Kazimierz (2004) Reportaż - jak go napisać? Poradnik dla stuchaczy studiów dziennikarskich. Warszawa: Wydawnictwa Szkole i Pedagogiczne.

Zagórski, Zygmunt (2006) “O sposobach badania składni i stylu tekstów.” [In:] Zygmunt Zagórski (ed.) Spisane stowa, formy i myśli. Studia z lat 1955-2001. Poznań: Wydawnictwo "Poznańskie Studia Polonistyczne"; 247-266.

Żak-Święcicka, Małgorzata (1993) Charakterystyka składniowa wypowiedzi dzieci w wieku przedszkolnym. Bydgoszcz: Wydawnictwo Uczelniane Wyższej Szkoły Pedagogicznej. 